\title{
The Implementation of the Precautionary Principle in Nuclear Safety Regulation: Challenges and Prospects
}

\author{
Miaomiao Yin ${ }^{1, *(D)}$ and Keyuan Zou ${ }^{2}$ (D) \\ 1 Guanghua Law School, Zhejiang University, Hangzhou 310000, China \\ 2 Law School, Dalian Maritime University, Dalian 116000, China; zoukeyuan@dlmu.edu.cn \\ * Correspondence: yinmiao_miao@163.com; Tel.: +86-17857004022
}

check for updates

Citation: Yin, M.; Zou, K. The Implementation of the Precautionary Principle in Nuclear Safety Regulation: Challenges and Prospects. Sustainability 2021, 13, 14033. https:// doi.org/10.3390/su132414033

Academic Editors: Barry David Solomon and Changhyun Roh

Received: 25 September 2021 Accepted: 15 December 2021 Published: 20 December 2021

Publisher's Note: MDPI stays neutral with regard to jurisdictional claims in published maps and institutional affiliations.

Copyright: (c) 2021 by the authors. Licensee MDPI, Basel, Switzerland. This article is an open access article distributed under the terms and conditions of the Creative Commons Attribution (CC BY) license (https:/ / creativecommons.org/licenses/by/ $4.0 /)$.
Abstract: The precautionary principle has been implemented in many fields including environment protection, biological diversity, and climate change. In the field of international nuclear safety regulation, the implementation of this principle is in an ongoing process. Since Japan declared to discharge Fukushima nuclear waste water into the ocean, the precautionary principle was put on the stage, and some debates are invoked on it. As is observed by this article, the precautionary principle has not been effectively implemented in nuclear safety regulation, specifically in nuclear safety law making, law enforcement, and judicial application. The reasons can be found from two main challenges: indeterminacy of perceived risk level required to justify precautionary action and hard balance of national interest and community interest in nuclear safety. In a long-term perspective, the framework of international nuclear safety regulation has to respond to these challenges, both by clarifying the precautionary principle in legal binding nuclear safety documents and moving towards a more transparent, fair, and effective enforcement regime in order to promote safer, more sustainable, and efficient civilian nuclear utilization around the world.

Keywords: the precautionary principle; nuclear safety regulation; community interest; UNCLOS; international law

\section{Introduction}

The civilian applications of nuclear energy are widespread in the contemporary word, among which, the development of nuclear electric power has attracted significant public and private investment [1] (p. 36). Nuclear power stations use nuclear fission to generate energy, and the reactors use nuclear fuel, the atoms of which are split in the process of fission, releasing a large amount of energy. However, the operation of nuclear installations is a process with high risk. In human history, there were several significant nuclear accidents, such as the Windscale Reactor accident in 1957, the Three Mile Island accident in 1979, the Chernobyl accident in 1986, and the Fukushima Daiichi nuclear accident in 2011. These accidents occurred in different areas but caused direct, indirect, material, invaluable, or trans-boundary damage. All these accidents raised great global concern on nuclear safety and aroused people's fear of nuclear power [2] (p. 1938).

Ten years after the 2011 Fukushima accident, on 13 April 2021, the Japanese government decided to start releasing treated radioactive water from the wrecked Fukushima nuclear plant into the Pacific Ocean two years later [3]. Divergent standpoints rose on the same event. The US [4] and officers of IAEA [5] supported the decision immediately. In contrast, South Korean [6] and Chinese authorities [7] expressed serious concern and began to discuss the legality of this decision. The Tokyo Electric Power Company ("TEPCO") demonstrated that the nuclear wastewater from Fukushima accident would be treated in multinuclide removal equipment ("ALPS") before being released and claimed it will not damage the environment [8]. Although there are still doubts involving the possible negative consequences caused by the released nuclear waste water [9], current scientific evidence is not comprehensive enough to demonstrate that the nuclear waste water release 
will damage human health and the ocean environment. A lack of well-recognized scientific evidence makes the precautionary principle particularly relevant in this case. The disagreement on the nuclear waste water recharge behavior provides a good chance to reconsider how the precautionary principle works to manage environmental and human health risks in nuclear safety fields. With this background, this article is not intended to discuss the scientific debates behind the nuclear waste water release but to focus on some legal issues: what role the precautionary principle plays in nuclear safety regulation and whether it has been implemented effectively, and, if it is not the case, why and how can we change the situation?

In the following part, this article will firstly review the relevance of the precautionary principle to nuclear safety regulation. Then, a primary evaluation of implementation of the principle during the nuclear safety law making, law enforcement, and the judicial application processes is provided. The evaluation results reveal that the precautionary principle has played a limited role in nuclear safety regulation in the last few decades despite its increasing significance. Subsequently, some key challenges accounting for the weak implementation of the principle are discussed in the next part. Lastly, this article will provide some insights on possible development and reformation prospects from legislation to law enforcement to enhance the implementation of the precautionary principle in international nuclear safety regulation.

\section{The Precautionary Principle and Nuclear Safety Regulation: An Overview \\ 2.1. Risks during Civil Nuclear Energy Production}

Risks surround virtually every aspect of civil nuclear energy production. As no industry is immune from accidents, the nuclear energy industry is no exception. The first aspect is the reactor safety. There have been evolving technologies on reactors since the inception of nuclear power on an industrial scale in the mid-20th century. The Three Mile Island, Chernobyl, and Fukushima accidents were all reactor accidents and demonstrated that reactors used in these plants were not safe enough $[10,11]$ (pp. 2, 1236). Nuclear fission reactor technologies have developed from Generation I to Generation III, and Generation IV is under research and projected to be deployed after 2030 [12] (pp. 325-343).

The second is decommissioning and clean-up, which involve programs to decontaminate, decommission, and clean up legacy facilities. Relevant technologies include robotics, radionuclide detection, and understanding the chemical, physical, and mechanical nature of the waste forms and their likely interactions with the materials in which they are encapsulated [13] (p. 175). Limitations on human knowledge on the qualities of nuclear atoms and the effects of radiation contribute to uncertainty during this stage.

The third is nuclear waste and spent fuel management and disposal, which encompass a sequence of activities from the management of spent fuel in nuclear reactors to the safe disposal of the unusable radioactive substances [14]. Scientists have revealed some defects in management of spent nuclear fuel by drawing lessons from the Fukushima accident [15] (p. 1225). For example, interim storage of spent fuel needs to be rethought, as densely packed spent fuel in pools may pose a radiation-release risk. Moreover, a long-term plan for the disposal of nuclear waste is required for nuclear energy production projects. In short, the way to manage spent fuel and nuclear wastes requires further examination, careful planning and well-executed policy.

\subsection{The Precautionary Principle as a Tool to Manage Risks}

The precautionary principle tells people what to do beyond the current state of knowledge and technology. It traces back to the German concept "Vorsorgeprinzip". The concept was included in German environmental policy in the 1970s [16]. The precautionary principle has become increasingly prevalent in international environmental law since the 1980s $[17,18]$ (pp. 9, 297). There are different versions of the precautionary principle in different documents, among which the most famous one is principle 15 of the Rio Declaration on Environment and Development ("the Rio Declaration"). From these versions, 
scholars abstracted the core elements of the precautionary principle. Arie Trouwborst called "threats; uncertainty; actions" as Apollo's Tripod [19]. Per Sandin proposed four dimensions of the precautionary principle, including the threat dimension, the uncertainty dimension, the action dimension, and the command dimension [20]. Deborah Katz listed four fundamental elements for the precautionary principle: level of risk, action to take, acknowledgment of benefits, and level of uncertainty/lack of consensus [21] (p. 957). Despite different views on the definition and elements, the essence of the principle is common and simple: Uncertainty should not be a reason for inaction in the face of serious environmental threats [22] (p. 11333). Daniel Steel called this essence a meta-precautionary principle and viewed it as the fundamental part of the principle [23] (p. 9). The precautionary principle functions as a framework of fundamental regulatory policies and provides broad guidelines to guide the formulation of more specific laws and public policy [24] (p. 29). It embodies that anthropogenic harm to human health and the environment should be avoided or minimized through anticipatory, preventive regulatory controls [25] (p. 13). The status of the precautionary principle in international law has been argued for many years. Some scholars hold the view that the precautionary principle has become customary international law [26,27] (pp. 262, 229-235), while others believe that it is still an emerging customary international law [28] (p. 88). Most scholars accepted it as a principle of law [29-32] (p. 57, p. 54, p. 6, p. 4), although it has no universal binding force itself and needs to be implemented through legally binding documents [16] (p. 22).

The precautionary principle is of immediate and widespread relevance in the nuclear safety context: firstly, it is a fact that human society has accepted risks brought by nuclear power in exchange for the gained benefits. It means the society has to pay for the costs and deal with the risks. Consequences of mass nuclear release after accidents can be devastating to both the environment and human lives, so measures should be developed by states and other actors to prevent nuclear accidents before accidents happen [33] (p. 721). Secondly, states have the responsibility of avoiding risks, especially when the decision may have a global impact. When states have to make decisions on construction of nuclear plants or management of nuclear wastes, a precautious and prudent consideration of environment is necessary, because these decisions pose risks to the rest of the world. Lastly, the requirement of sustainable development also makes it natural to implement the precautionary principle in nuclear safety. The realization of sustainable development requires the incorporation of environmental considerations in each industry. States are required to take actions to prevent the harmful impact to the environment in developing nuclear energy.

\section{A Preliminary Evaluation of the Implementation of the Precautionary Principle in Nuclear Safety Regulation}

\subsection{The Implementation in Nuclear Safety Law Making}

Current international nuclear safety law and other normative instruments were shaped by significant accidents and disasters in the past [34], with most of the documents adopted under the host of International Atomic Energy Agency ("IAEA"). During a reflection on how to avoid these accidents, the idea of precaution emerged and developed gradually. At the very beginning, preventive ideas dominated civilian nuclear safety regulations. It was not until the end of 1980s, prompted by the waves of environmental campaigns worldwide and reflections to the Chernobyl accident, that the precautionary principle began to be incorporated in international nuclear safety documents.

The implementation of the precautionary principle in IAEA documents has undergone four stages.

In the first stage, initial nuclear safety guidelines only reflected preventive ideas. After the Three Mile Island accident, IAEA began to consider development of an assistance framework for nuclear accidents since 1982. With continuous efforts, IAEA published two guidelines in 1984 and 1985: Guidelines for Mutual Emergency Assistance Arrangements in Connection with a Nuclear Accident or Radiological Emergency ("Mutual Emergency Assistance Guidelines"), and Guidelines on Reportable Events, Integrated Planning and Information Exchange in Transboundary Release of Radioactive Materials ("Integrated 
Planning and Information Exchange Guidelines"). Aimed at prevention of radiological consequences of nuclear accidents, the two guidelines marked a start of notification and assistance regimes in nuclear safety regulation. Although these guidelines do not impose any legal obligations on states, they appeal to prevent serious consequences of nuclear accidents and promoted adoptions of regional and bilateral treaties to enhance nuclear safety such as the 1963 Nordic Mutual Emergency Assistance Agreement [35] (p. 658).

In the second stage, Convention on Early Notification of a Nuclear Accident ("the Early Notification Convention") and Convention on Assistance in the Case of a Nuclear Accident ("the Assistance Convention") made a breakthrough from preventive logic towards precautionary logic. A few months after the Chernobyl accident, in September 1986, IAEA prompted the conclusion of the two important conventions. A precautionary idea is shown in article 1 of the Early Notification Convention, which stipulates that the convention shall be applied "in the event of any accident from which a release of radioactive material occurs or is likely to occur and which has resulted or may result in an international trans-boundary release that could be of radiological safety significance for another state" [36]. Different from previous guidelines, the Early Notification Convention requires contracting parties to notify before a radiological release may occur, which means that potentially affected states are entitled a legal right to obtain information and assistance.

In the third stage, the precautionary principle was defined in a more explicit way. In June 1992, Agenda 21 was launched at the United Nations Conference on Environment and Development. Article 5 of chapter 22 of the agenda, under the title of "safe and environmentally sound management of radioactive wastes", says,

"Not promote or allow the storage or disposal of high-level, intermediate-level and low level radioactive wastes near the marine environment unless they determine that scientific evidence, consistent with the applicable internationally agreed principles and guidelines, shows that such storage or disposal poses no unacceptable risk to people and the marine environment or does not interfere with other legitimate uses of the sea, making, in the process of consideration, appropriate use of the concept of the precautionary approach [37]."

The precautionary approach relates to the precautionary principle closely. It is thought that generally they are the same in meaning and can be replaced by each other [38] (p. 239).

In the same year, IAEA began drafting a nuclear safety convention and organized an extended group of technical and legal experts from almost fifty states and international organizations such as the European Commission, the Organization for Economic Cooperation and Development ("OECD"), and the Nuclear Energy Agency [39]. Two years later, the Convention on Nuclear Safety was open to signature. The convention recognizes the great safety risks posed by nuclear facilities due to the magnitude of stored energy and the inventory of radioactive isotopes, and it also establishes a comprehensive framework to ensure the safety of nuclear installations. The precautionary principle was reflected in many provisions. Firstly, article 1(3) of the Convention on Nuclear Safety defines that one of its objectives is to "prevent accidents with radiological consequences and to mitigate such consequences should they occur", which is consistent with the "uncertainty" dimension of the precautionary principle. Secondly, in the preamble, the convention defines the purpose to ensure the use of nuclear energy to be "safe, well regulated and environmentally sound", which means there are "threats" if the nuclear energy safe use is not well regulated. In the preamble, it also states that "accidents at nuclear installations have the potential for trans-boundary impact", and according to the ordinary meaning, the potential for transboundary impacts composes a threat to other states. These expressions reflect the "threats" dimension of the precautionary principle. Lastly, article 14 obligates contracting parties to implement comprehensive and systematic safety assessments before construction and commissioning of nuclear installation, which is consistent with the "action" dimension of the precautionary principle. The requirement of "comprehensive and systematic safety assessments" is to ask states to be precautious before starting nuclear related activities. The standards for "comprehensive and systematic safety assessments" can be found in the 
Joint Convention on the Safety of Spent Fuel Management and on the Safety of Radioactive Waste Management ("the Joint Convention") and systematic safety standards published by IAEA.

In March 1995, the IAEA convened a board of governors, and the group adopted "the Principles of Radioactive Waste Management", which laid a good foundation for subsequent convention negotiations. Two years later, the Joint Convention was adopted in December 1997. Understood as a whole, the Joint Convention also reflects the precautionary principle. It conceives "threats" behind radioactive materials as background knowledge and prohibits the unplanned and uncontrolled release of them into the environment. Furthermore, the "actions" dimension of precautionary ideas lies in the requirement of "systematic safety assessment" in paragraph 1, article 8 of the Joint Convention [40], which is consistent with the Convention on Nuclear Safety. In the following paragraph 2 of article 8 , it further stipulates the requirement of safety assessment, "updated and detailed versions of the safety assessment and of the environmental assessment is required to be prepared before the operation of a spent fuel management facility". Other standards for a qualified safety assessment include "International Basic Safety Standards for Protection against Ionizing Radiation and for the Safety of Radiation Sources (1996)", the IAEA Safety Fundamentals entitled “The Principles of Radioactive Waste Management (1995)", and the existing international standards related to the safety of the transport of radioactive materials, as is listed in the preamble of the Joint Convention [41].

In the last stage, 4 years after the 2011 Fukushima accident, the Vienna Declaration on Nuclear Safety on Principles for the Implementation of the Objective of the Convention on Nuclear Safety to Prevent Accidents and Mitigate Radiological Consequences ("the Vienna Declaration on Nuclear Safety") was adopted by the IAEA contracting parties in 2015 [42]. The declaration emphasizes the deficiency of the effectiveness of the Nuclear Safety Convention [43] (p. 35) and proposes three principles to strengthen its implementation, with "comprehensive and systematic safety assessments" as the second principle. Compared with previous conventions, this document does not go further in terms of implementing the precautionary principle.

It is clear to see the increasing awareness of the precautionary principle in nuclear safety documents during the last few decades. A primary conclusion is that the precautionary principle has been implemented in a flexible way in nuclear safety legislation. The principle is embedded in different terms in nuclear safety documents, although its meaning is not articulated in legally binding nuclear safety treaties or conventions.

\subsection{The Implementation in Nuclear Safety Law Enforcement}

Current enforcement mechanisms in nuclear safety regulation mainly refer to mechanisms maintained by IAEA. IAEA is responsible for organizing review meetings for contracting parties of the Nuclear Safety Convention every year. Both the Convention on Nuclear Safety and the Joint Convention have established an annual review meeting mechanism. Many issues have been discussed at review meetings in the past. IAEA also set up the Commission on Safety Standards ("CSS"), which is a standing body of senior government officials holding domestic responsibilities for establishing standards and other regulatory documents relevant to nuclear, radiation, transport and waste safety, and emergency preparedness and response. Since its establishment, CSS has convened 50 meetings, and the 51st meeting will be held during 19 to 22 April 2022 [44]. IAEA created the Operational Safety Review Team ("OSART") program in 1982. Until December 2020, IAEA conducted 210 OSART missions at 118 nuclear power plants in 37 Member States [45].

Peer review is a primary way to implement nuclear safety principles and standards. In the context of nuclear safety, peer review is manifested in two different forms: safety review services provided by OSART and review meetings under the nuclear safety conventions [46] (pp. 430-431). However, the review meetings only examine the report submitted by states in a very weak sense. Contracting parties of the Nuclear Safety Convention either did not 
submit their national report or did not submit their national report to the secretariat in time to support effective review by other contracting parties [47]. Even if the report is submitted, the validity of data on the report cannot be verified.

Furthermore, the gaps in technology and economic developing level between states make it impossible for OSART to supervise the domestic implementations. Article 8 of the Nuclear Safety Convention stipulates that contracting parties should establish or designate regulatory bodies to implement the legislative and regulatory framework, and these bodies should be provided with adequate authority, competence, and financial and human resources to fulfill its assigned responsibilities. The reality is, for some states, the competence and financial and human resources of regulatory bodies can hardly be guaranteed, so that it is impossible for them to implement the precautionary principle. According to the World Nuclear Association, about 30 states are considering, planning, or starting nuclear power programs, and a further 20 or so states have, at some point, expressed interests. In Asia, major economies including China and India are expanding nuclear energy to help meet their growing power needs. Bangladesh and Turkey have begun construction of their first nuclear power plants, and in Egypt, nuclear power is well into its development phase [48] (p. 1131). These states new to nuclear enterprise may not have the capability to safely manage and regulate civil reactors [11] (p. 1236). Differences in national economic development level imply not all states can support independent, qualified, and responsible regulatory bodies.

These observations reveal that IAEA has weak executive power, and current peer review mechanisms in nuclear safety regulation have many deficiencies. It is not difficult to imagine that not all domestic regulatory bodies will shoulder their responsibility strictly. A natural conclusion is the implementation of the precautionary principle cannot be ensured in such problematic enforcement mechanisms in nuclear safety regulation.

\subsection{The Implementation in International Judicial Application}

The judicial application of the precautionary principle in nuclear safety has been dealt with by international tribunal in the mixed oxide fuel ("MOX") plant case between Ireland and the UK. In late October 2001, Ireland instituted proceedings against the UK and required the adjudication of the tribunal under the arbitration provisions of the United Nations Convention on the Law of the Sea ("UNCLOS"). Before the arbitral tribunal was set up, Ireland also submitted a request that the International Tribunal for the Law of the Sea ("ITLOS") prescribe for provisional measures. The hot debates between the two parties before the tribunal on the precautionary principle as well as the judgement presented whether and how the precautionary principle can be applied in nuclear activities.

In that case, Ireland claimed the UK had a policy of discharging nuclear wastes directly into the Irish Sea by authorizing the MOX plant and thermal oxide reprocessing plant ("THORP") plant to operate, which brought great risks to Ireland and caused pollution in the marine environment. One focus of the debates is whether the nuclear release from the MOX plant and THORP plant comprises an "irreversible or serious harm". Ireland believes the nuclear waste release is no doubt a substantial pollution and the precautionary principle should apply, which means the UK needs to take proper precautionary actions or stop the nuclear release. The arguments of Ireland include: firstly, substantial pollution should be not judged only by volume, but also the continuous and persistent nature and the longevity of the radionuclides [49] (pp. 27-58). Ireland argued that, considering that plutonium was one of the most radioactive materials known to man, the half-life of $\mathrm{Pu}$ 229 was 24,065 years, and the discharge was projected to be continuous till 2020 or 2024, so it could cause severe consequences. Then, Ireland provides evidence to show living organisms can be affected even at low dose radiation [50] (p. 57). According to research results by scientists, low dose radiation could cause a pulsed or acute exposure and create a phenomenon of genomic instability and bystander effect [50] (p. 58). With the bystander effect, cells exposed to low and very low doses of radiation can produce a factor that affects the survival and function of unexposed cells. Another study also shows that all daughter 
cells of the parent cell had an increased probability of developing a totally unpredictable and random mutation somewhere in the DNA. Some may be lethal. From the perspective of the UK, the fact that radionuclides have a long half-life cannot demonstrate a likelihood of irreparable damage or serious harm [50,51] (pp. 24-31, p. 16-20). The UK defends that during the assessment period (1986-2002), the estimated dose rates to marine biota in the vicinity of Sellafield were found to be even lower than the levels suggested in the literature, at which effects on aquatic organisms at a population level would be unlikely [50] (p. 9). Substantial pollution means the introduction of substances into the marine environment that result or are likely to result in harm, where likelihood means 50.1 per cent or more. If Ireland cannot prove it, the precautionary principle does not apply [50] (p. 84).

On 3 December 2001, ITLOS issued its order. The order shows that ITLOS adopted a constraint attitude to fortify the status of the precautionary principle by avoiding mentioning it in conclusion part. A main reason was that it is not appropriate for ITLOS to decide on it. Nevertheless, judges provided their views on application of the precautionary principle in separate declarations. Most judges believed there was lack of sufficient scientific evidence on possible consequences of the operation of the MOX plant on the marine environment of the Irish Sea [52] (p. 113), and only one judge believed the precautionary principle should apply. Specifically, judge David Anderson, Thomas A. Mensah, and Tullio Tieves believed that the scientific evidence is not substantial enough, and the evidence did not suffice to show irreversible or serious harm to the marine environment so the tribunal should not consider the precautionary principle [53-56]. Judge Rüdiger Wolfrum acknowledged the high relevance of the precautionary principle in this case, and the result of applying this principle would be that "a state interested in undertaking or continuing a particular activity has to prove that such activities will not result in any harm, rather than the other side having to prove that it will result in harm [56] (p. 133)". A different standard can be found from judge ad hoc Alberto Székely, who showed the strongest support for the application of the precautionary principle in this case. In his view, the tribunal should give the benefit of the doubt on the risk of harm alleged by Ireland to Ireland rather than the UK [57] (p. 147).

Overall, by scrutiny of the case, two observations can be listed here: On the one hand, the separate opinions of judges showed applicability of the Precautionary Principle in nuclear safety field, which could benefit the future judicial implementation of the principle in this field. On the other, the debates of parties and the judgement showed the complexity and difficulties to apply the precautionary principle in the nuclear activities, as there are no clear, agreed standards in the principle itself.

\section{Key Challenges behind the Implementation of the Precautionary Principle}

Having examined the implementation of the precautionary principle in law making, law enforcement, and judicial application, it can be concluded that the principle has not been effectively implemented, at least not in law enforcement and judicial application stages. Before proposing any recommendations to improve the situation, this article identified two key challenges behind current implementation status. One is about the complexity of the principle itself, and the other is about the political willingness.

\subsection{Indeterminacy of Perceived Risk Level Required to Justify Precautionary Action}

It is known that the precautionary principle aims to deal with serious uncertain risks for the natural environment and public health. However, one of the key challenges of implementing the precautionary principle in nuclear safety regulation is how to draw the line of threshold of precautionary actions.

\subsubsection{How to Define Uncertainty and Risks}

It is clear that, in the MOX plant case, the two parties had different opinions on whether the precautionary principle can be applied, facing similar scientific evidence. Behind the dispute, the true question is in which level risks perceived in nuclear activities 
can justify the precautionary actions to regulate them, and what types of precautionary actions are necessary.

To address the question, firstly, it should be made clear how uncertainty and risks are presented in nuclear related policy-making. Risk is a concept closely related to uncertainty [58] (p. 317). In a social sense, the fact that people need to make decisions under uncertainties means risks are unavoidable. Complexity in practice means a compulsion to select, and contingency means danger of disappointment and the necessity to take risks [59] (p. 25). Wynne clarifies risk as a state that "system behavior is basically known, and outcomes can be assigned a probabilistic value [60]". Risk analysis is a process combined with objective calculation and a subjective estimate of the consequences [61]. In the nuclear safety field, the risks can be characterized by complexity, spatial and temporal extent, potential catastrophe, improbability, diverse uncertainties, plurality of perspectives, and learning-with-time [62] (p. 127).

Considered from a scientific lens, the notion of uncertainty derives from probability theory and quantum physics [63]. In a "post-modern" appreciation of science, uncertainty always exists [64] (p. 501), which is based on the limitation of scientific knowledge and human activities [65] (p. 92). The validity of scientific knowledge may change with time [66]. Due to different development levels of science and technology, the level of uncertainty vary in different fields. There is an entire spectrum of different levels of knowledge, ranging from the unachievable ideal of complete deterministic understanding to total ignorance [67] (p. 11). The certainty of damage brought by radioactive materials are somewhere in the middle. However, one important factor to consider is the increased availability of scientific evidence. A common criticism of the precautionary principle is that it may lead regulators to make bad choices because the public tends to be overly fearful of certain immediate risks that are statistically far less dangerous [68,69] (p. 33, pp. 177-178). This is often not the case today. Firstly, now much more materials are available for the public with the continuous efforts of organizations, such as International Commission on Radiological Protection. The nuclear pollution has become a common debate, which no doubt helps the public to form a relatively objective opinion about nuclear atoms. Secondly, the consequence of radiation on animals and plants has been elaborated by much more sophisticated assessment technologies. Much more evidence is given of the potential impact of radionuclides than in the past, when the MOX plant case was challenged. For example, impact on an organism resulting from a given absorbed dose of ionizing radiation has been experimentally quantified and reported as relative biological effectiveness of specific radiation types [70].

\subsubsection{The Strictness of the Precautionary Principle}

For policy-makers, uncertainty exists in practically all policy making situations. It cannot be eliminated, but confusion can be arguably best reduced to a minimum by drawing a line using law and policy as a tool [66] (p. 195). Then, a further question is where policymakers should draw the line of perceived risk level for a defensible precautionary [71] (p. 63), i.e., how strict the precautionary principle should be. After many years' debates, the precautionary principle was classified into strong form and weak form [72] (p. 68), according to the strictness of the requirement of actions [25] (p. 20). In its strong form, where a very low level of perceived risk is permitted, a "morally unacceptable harm" with "scientifically plausibility" will trigger the precautionary principle. By contrast, in its weak form, a larger level of perceived risk is tolerated [73] (p. 10892), and only "threats of serious or irreversible damage" can trigger it.

Deville and Harding proposed a rule to help determine the strictness of the precautionary principle, which is "the more significant and uncertain the threat is, the greater the precaution required [74] (pp. 121-122)". This provides an indication of how to locate the threshold level of the precautionary principle in nuclear safety. In nuclear safety fields, the threat known is increasing, and the uncertainty is decreasing. On the one hand, new impacts of the radiation brought by low dose radionuclides are being better demonstrated 
and disclosed. On the other, scientific uncertainty is decreasing a the scientific evidence becomes more sufficient, which means that the precautionary principle allows less uncertainty. Overall, a moderate perceived risk level is required by the precautionary principle. In other words, in nuclear safety, a moderate form of the precautionary principle should be adopted, and the perceived risk level should be between "morally unacceptable harm that is scientifically plausible" and "threats of serious or irreversible damage when lack of full scientific certainty".

\subsection{The Hard Balance of National Interest and Community Interest in Nuclear Safety}

Another significant challenge to the implementation of the precautionary principle in international nuclear safety regulation is the hard balance between national interest and community interest. A significant deficiency of the current nuclear energy law is that it only encourages states to implement the nuclear safety rules themselves, therefore giving broad discretionary power to policy-makers [44] (p. 28). It is easy to understand the unwillingness of states to pay costs of precautionary actions to assure community interest, especially the interests of potentially affected states and non-nuclear states.

\subsubsection{Inconsistency between the Beneficiaries and Risk Takers}

In terms of nuclear activities, there is an inconsistency between the beneficiaries and risk takers. An important character of nuclear safety regulation is its special type of decision-making options. The beneficiaries of approval of nuclear facility constructions are nuclear states, mostly developed states [75], while the cost of damage risk is borne by the international community. Compared with other areas such as biodiversity conservation, where "multiple risks" are involved [76], the situation in nuclear safety regulations faced by decision-makers is often a one-in-two choice: "national interest first" or "community interest first". A "national interest first" situation means that states prioritize their economic benefits and the health of nationals. States are motivated to build more nuclear reactors and installations, produce carbon-free electricity, lower the average retail price of electricity, and achieve industrial upgrading. Meanwhile, in terms of risks brought by nuclear accidents and nuclear waste release, they seek to protect their industry and domestic victims [77] (p. 209), regardless of risks posed to the international community. In this way, they can achieve a maximum of national interest. A "community interest first" situation means that, when risks are involved during nuclear activities, states seek to ensure the interest of most vulnerable groups of the world and can take actions to control the threats, even at the cost of prohibition of the nuclear activity.

From a realistic perspective, states always choose to develop their nuclear infrastructures on a self-benefit basis and neglect the environmental interest of the international community. This leads to political maneuvering involving the implementation of the precautionary principle [25] (p. 14). For example, the plants may adopt a wrong way of calculation of radioactivity to make the operation more permissible, and the regulatory bodies indulge them in pursuit of national economic interests. In the MOX plant case, the UK claimed that discharges from the THORP plant were very small, far lower than specific or site limits set in accordance with domestic and European regulations. The doses from the THORP plant were a fraction of 1 percent of natural background radiation [50] (p. 7). Ireland argued that the MOX plant used a wrong method of calculation that underestimated the "total beta" radioactivity actually discharged. It was not based on the Environmental Agency approved method for complex sites such as Sellafield. In this way, it underestimated the "total beta" radioactivity actually discharged. If the accusation of Ireland is true, the behavior of the UK would be a typical example of "national interest first" behavior and infringes community interest.

\subsubsection{The Insufficient Protection of Community Interest}

Community interest is also not protected adequately under current peer review mechanisms. Under current peer review mechanisms, experts will examine the safety of nuclear 
installations and activities according to nuclear safety standards made by CSS. The composition rules of CSS indicate the potential inequality in discourse of standards-making between developed states and less developed states. The discourse power of economically less developed states may be deprived by the cost of participation. According to the rule on CSS conferences, "all costs involved in the participation of each CSS member, including travel and per diem expenses, will be borne by the nominating member State" [78]. It means less developed states may have a poor access to CSS and standards-making. Obviously, the CSS members from developed states will be present on behalf of their national interests. For instance, when they are defining what is "best available scientific information and technologies", they may firstly consider the available technologies in their states. In this case, the difference of development levels among states may lead to a hegemonic standardsmaking and substantial inequity. Lack of participation of less developed states leads to neglect of their interests. The effective implementation of the precautionary principle in these states is therefore adversely affected.

To conclude, the "national interest first" logic of states hinders the implementation of the precautionary principle in nuclear safety regulation. It necessitates a more effective, fair, well designed implementation framework in nuclear safety fields.

\section{Future Prospects for Better Implementation of the Precautionary Principle}

As global concerns for nuclear safety and sustainable development increase, the demand to promote implementation of the precautionary principle in nuclear safety will only become more and more strong. The effective implementation of the principle depends on the responses to the challenges mentioned above. Two possible directions can be considered to address the challenges: clarify the precautionary principle in nuclear safety law making and move towards more transparent, fair, and effective law enforcement regimes.

\subsection{Clarifying the Precautionary Principle in Nuclear Safety Law Making}

\subsubsection{The Precautionary Principle Established in Formal Documents of Other Fields}

Some scholars criticize the precautionary principle as paralyzing, because it is widely varying, often incredibly vague $[79,80]$ (p. 10790, p. 7). Sonia Boutillon describes it as an "unsettled formulation" [81] (p. 433). A solution is to elaborate the precautionary principle in each specific situation, based on its general meaning under principle 15 of the Rio Declaration. For example, in biological diversity, the precautionary principle has been clarified by Convention on Biological Diversity. In climate change, it has been clarified by 1992 United Nations Framework Convention on Climate Change. It is feasible to define such a principle in nuclear safety regulation. The clarification of the precautionary principle in nuclear safety regulation can refer to the established precautionary rules in other fields such as environment protection.

From Table 1, it can be seen that four provisions involving the precautionary principle are legally binding, which include: article 206 of the 1982 UNCLOS, article 3.3 of the 1992 United Nations Framework Convention on Climate Change, article 3 of the 1996 Protocol to the Convention on the Prevention of Marine Pollution by Dumping of Wastes and Other Matter ("1996 Protocol to the London Convention"), and article 2(2)(a) of the OSPAR Convention. These legally binding documents provide a reference for establishing an exclusive rule of the precautionary principle in nuclear safety conventions. 
Table 1. Different Expressions of the Precautionary Principle.

\begin{tabular}{|c|c|c|c|}
\hline Types of Documents & Name of the Document & Expression & Level of Perceived Risk \\
\hline Declaration & $\begin{array}{l}1987 \text { Ministerial Declaration } \\
\text { on Second International } \\
\text { Conference on the Protection } \\
\text { of the North Sea (Article 7) }\end{array}$ & $\begin{array}{l}\text { "Accepting that, in order to protect } \\
\text { the North Sea from possibly } \\
\text { damaging effects of the most } \\
\text { dangerous substances, a } \\
\text { precautionary approach is necessary } \\
\text { which may require action to control } \\
\text { inputs of such substances even before } \\
\text { a causal link has been established by } \\
\text { absolutely clear scientific evidence." }\end{array}$ & $\begin{array}{l}\text { possibly damaging effects of } \\
\text { the most dangerous } \\
\text { substances; before a causal } \\
\text { link has been established by } \\
\text { absolutely clear } \\
\text { scientific evidence }\end{array}$ \\
\hline
\end{tabular}

"when States have reasonable grounds for believing that planned activities under their jurisdiction or control may cause substantial pollution of or significant and harmful changes to the marine environment, they shall, as far as practicable, assess the potential effects of such activities on the marine environment."

\section{"In order to protect the environment,} the precautionary approach shall be widely applied by States according to their capabilities. Where there are threats of serious or irreversible damage, lack of full scientific certainty shall not be used as a reason for postponing cost-effective measures to prevent environmental degradation."
"Noting also that where there is a threat of significant reduction or loss

Convention 1992 Convention on Biological Diversity (preamble) of biological diversity, lack of full scientific certainty should not be used as a reason for postponing measures to avoid or minimize such a threat." have reasonable grounds; may cause substantial pollution of or significant and harmful changes to the marine environment
"Contracting Parties shall apply a precautionary approach to environmental protection from

1996 Protocol to the

Convention
Convention on the Prevention of Marine Pollution by Dumping of Wastes and Other Matter (article 3) dumping of wastes or other matter whereby appropriate preventative measures are taken when there is reason to believe that wastes or other matter introduced into the marine environment are likely to cause harm even when there is no conclusive evidence to prove a causal relation between inputs and their effects" a threat of significant reduction or loss of biological diversity; lack of full scientific certainty appropriate preventative measures; likely to cause harm; no conclusive evidence to prove a causal relation 
Table 1. Cont

\begin{tabular}{|c|c|c|c|}
\hline Types of Documents & Name of the Document & Expression & Level of Perceived Risk \\
\hline Convention & $\begin{array}{l}1992 \text { United Nations } \\
\text { Framework Convention on } \\
\text { Climate Change (article 3.3) }\end{array}$ & $\begin{array}{l}\text { "The Parties should take } \\
\text { precautionary measures to anticipate, } \\
\text { prevent or minimize the causes of } \\
\text { climate change and mitigate its } \\
\text { adverse effects. Where there are } \\
\text { threats of serious or irreversible } \\
\text { damage, lack of full scientific } \\
\text { certainty should not be used as a } \\
\text { reason for postponing such measures, } \\
\text { taking into account that policies and } \\
\text { measures to deal with climate change } \\
\text { should be cost-effective so as to } \\
\text { ensure global benefits at the lowest } \\
\text { possible cost." }\end{array}$ & $\begin{array}{l}\text { threats of serious or } \\
\text { irreversible damage; lack of } \\
\text { full scientific certainty }\end{array}$ \\
\hline Convention & $\begin{array}{l}1998 \text { Convention for the } \\
\text { Protection of the Marine } \\
\text { Environment of the } \\
\text { North-East Atlantic ("the } \\
\text { OSPAR Convention") } \\
\text { (Article 2(2)(a)) }\end{array}$ & $\begin{array}{l}\text { the precautionary principle, by virtue } \\
\text { of which preventive measures are to } \\
\text { be taken when there are reasonable } \\
\text { grounds for concern that substances } \\
\text { or energy introduced, directly or } \\
\text { indirectly, into the marine } \\
\text { environment may bring about } \\
\text { hazards to human health, harm living } \\
\text { resources and marine ecosystems, } \\
\text { damage amenities or interfere with } \\
\text { other legitimate uses of the sea, even } \\
\text { when there is no conclusive evidence } \\
\text { of a causal relationship between the } \\
\text { inputs and the effects. }\end{array}$ & $\begin{array}{l}\text { reasonable grounds for } \\
\text { concern; take preventive } \\
\text { measures; hazards to human } \\
\text { health, harm living resources } \\
\text { and marine ecosystems }\end{array}$ \\
\hline $\begin{array}{c}\text { Report of } \\
\text { Non-Governmental } \\
\text { Organization }\end{array}$ & 1998 Wingspread statement & $\begin{array}{l}\text { "When an activity raises threats of } \\
\text { harm to human health or the } \\
\text { environment, precautionary measures } \\
\text { should be taken even if some cause } \\
\text { and effect relationships are not fully } \\
\text { established scientifically." }\end{array}$ & $\begin{array}{l}\text { raises threats of harm to } \\
\text { human health or the } \\
\text { environment; cause and effect } \\
\text { relationships are not fully } \\
\text { established scientifically }\end{array}$ \\
\hline $\begin{array}{c}\text { Report of } \\
\text { United Nations }\end{array}$ & 2005 COMEST report & $\begin{array}{l}\text { "When human activities may lead to } \\
\text { morally unacceptable harm that is } \\
\text { scientifically plausible but uncertain, } \\
\text { actions shall be taken to avoid or } \\
\text { diminish that harm." }\end{array}$ & $\begin{array}{c}\text { may lead to morally } \\
\text { unacceptable harm; } \\
\text { scientifically plausible } \\
\text { but uncertain }\end{array}$ \\
\hline
\end{tabular}

\subsubsection{Reference Significance of Article 206 of UNCLOS}

Actually, the purpose of nuclear safety regulation entails the consideration of marine environment protection. There are some similarities between environment pollution and nuclear radiation. For example, nuclear release seems to comprise pollution under UNCLOS. Article 1 of UNCLOS defines:

"Pollution of the marine environment" means "the introduction by man, directly or indirectly, of substances or energy into the marine environment, including estuaries, which results or is likely to result in such deleterious effects as harm to living resources and marine life, hazards to human health, hindrance to marine activities, including fishing and other legitimate uses of the sea, impairment of quality for use of sea water and reduction of amenities; which imposes a restraint on the discharges or releases of toxic materials."

According to the ordinary meaning, radionuclide is a kind of substance that is likely to result in deleterious effects. This indicates that the precautionary requirements between 
marine environment protection and nuclear safety regulation are consistent. Therefore, the wording of the precautionary principle in nuclear safety can be similar to article 206 of UNCLOS. On the other hand, the threshold defined in article 206 of UNCLOS is "may cause substantial pollution or significant and harmful changes to the marine environment", which is too vague in the nuclear safety context to help with its implementation, so criteria of the precautionary principle in nuclear safety should be made more clear based on article 206 of UNCLOS.

\subsection{Moving towards More Transparent, Fair, and Effective Enforcement Regimes}

As more and more states and regions including less-developed ones show the tendency to develop nuclear energy to hold the promise of decarbonizing transport and industry, as well as electricity, the concerns and discussions on nuclear safety will be more and more widespread. It is a long-term sustainable development goal to "ensure access to affordable, reliable, sustainable and modern energy for all" [82], and it is no doubt important for nuclear safety to be given more attention.

Therefore, a complete and effective implementation regime of the precautionary principle is indispensable. New regimes should take community interest into account substantially and balance the interests of developed and less developed states. For example, the monopoly of discourse by developed states in peer review and standards-making processes could be improved by designing a mechanism that ensures neutrality of CSS members. Capacity building programs also help to implement the precautionary principle in nuclear safety regulation, as the monopoly of technology by developed states hinders the adoption of advanced nuclear technologies in less developed states. Differences in technology development level make it difficult to implement the same standards to states all over the globe. Capacity building of least developed states should be given more priority, as is required in the United Nations Declaration "Transforming Our World: The 2030 Agenda for Sustainable Development" ("Agenda 2030") [82]. Furthermore, the deficiencies of self-regulation of states must be taken into account to protect community interest and achieve a higher level of nuclear safety.

Based on all these considerations, some prospects of regime reformation are proposed here:

Firstly, enhancing the executive power of IAEA is a possible effective way to maintain nuclear safety on a global level. The current safety examination regime operated by OSART based on voluntary invitation of states may be replaced by a mandatory examination regime in certain circumstances in the future, which is crucial for implementing the established nuclear safety standards and the precautionary principle. Secondly, formal regimes of nuclear capacity building should be further developed. Lastly, CSS could engage scientists and experts who are financially independent from states to overcome the interference of national interests.

\section{Conclusions}

Although scientific knowledge and technologies on nuclear energy production have made many breakthroughs, humans still do not know what precautionary measures are proper to avoid nuclear accidents effectively. That is why the precautionary principle should be developed and implemented. However, after scrutiny in law making, law enforcement, and judicial application stages, it is found the principle stagnated on the surface of the nuclear safety documents, without being carried out strictly in enforcement and being applied widely in judicial cases in the last few decades.

Actually, the limited role of the precautionary principle in nuclear safety can be attributed to at least two deep-rooted sources, from both the inside aspect of the principle and the outside one about political preference of national interests, respectively. For the inside reason, the threshold of the precautionary principle is not very clear in nuclear safety regulation currently. For the outside reason, the meaning of community interest in nuclear activities tends to be neglected and calls for further definition. 
To respond to the challenges, improvements in the legislation level and the enforcement level should be considered. During the next diplomatic conference to consider proposals to amend the Convention on Nuclear Safety, the incorporation of Precautionary Principle into the Nuclear Safety Convention can be discussed. The focal point of the discussion should be clarification of the principle in a technical sense, considering that increasing knowledge of nuclear impact has reduced the extent of uncertainty and more risks are identified. Additionally, enforcement regimes reformation in international nuclear safety regulation can be initiated based on fair balance of national interest and community interest. Specifically, under current the IAEA enforcement framework, the executive power of IAEA needs to be strengthened, and the monopoly of developed states on discourse and technology should be eliminated by more capacity building programs.

As more and more states are planning to develop nuclear energy and construct their own nuclear plants, there are practical needs to promote comprehensive implementation of the precautionary principle in nuclear safety regulation. With the background that the nuclear waste water recharge decision of Japan induces global concern for its impact on the global marine environment, it is time for the international community to stop and consider promotion of the implementation of the precautionary principle to achieve a higher level of nuclear safety.

Author Contributions: Supervision, K.Z.; Writing—original draft, M.Y.; Writing—review \& editing, M.Y. and K.Z. All authors have read and agreed to the published version of the manuscript.

Funding: This paper is part of a research project funded by China's National Social Sciences Foundation (18VHQ002).

Institutional Review Board Statement: Not applicable.

Informed Consent Statement: Not applicable.

Data Availability Statement: Not applicable.

Acknowledgments: The author is grateful to Jing Jin, Sen Wang (Zhejiang University) for providing generous support on proofreading.

Conflicts of Interest: The authors declare no conflict of interest.

\section{References}

1. Dittmar, M. Nuclear energy: Status and future limitations. Energy 2012, 37, 35-40. [CrossRef]

2. Davies, L.L. Beyond Fukushima: Disasters, Nuclear Energy, and Energy Law. Brigham Young Univ. Law Rev. 2011, 6, 1937-1990.

3. Inter-Ministerial Council for Contaminated Water. Treated Water and Decommissioning Issues. 13 April 2021. Available online: https:/ /japan.kantei.go.jp/99_suga/actions/202104/_00012.html (accessed on 24 November 2021).

4. Press Statement. Available online: https://www.state.gov/government-of-japans-announcement-on-fukushima-treated-waterrelease-decision/ (accessed on 24 November 2021).

5. IAEA. Ready to Support Japan on Fukushima Water Disposal. Available online: https://www.iaea.org/newscenter/pressreleases/ iaea-ready-to-support-japan-on-fukushima-water-disposal-director-general-grossi-says (accessed on 24 November 2021).

6. South Korea Mulls Court Fight over Japan's Plan to Release Contaminated Fukushima Water. Available online: https://www.cbc. $\mathrm{ca} /$ news / world / fukushima-nuclear-water-1.5986603 (accessed on 24 November 2021).

7. China Slams Japan's Plan to Release Water from Nuclear Plant into the Sea. Available online: https://www.msn.com/enin/money/topstories / china-slams-japan-s-plan-to-release-water-from-nuclear-plant-into-the-sea/ar-BB1fAzfZ (accessed on 24 November 2021).

8. Tokyo Electric Power Company Holdings, Inc. New Definition of ALPS Treated Water and the Amount of Tritium in Water Being Stored in Tanks. Available online: https://www.tepco.co.jp/en/decommission/progress/watertreatment/images/20210427.pdf (accessed on 24 November 2021).

9. Buesseler, K.O. Opening the floodgates at Fukushima. Science 2020, 369, 621-622. [CrossRef] [PubMed]

10. Weinberg, A.M. Three Mile Island in perspective: Keynote address. Ann. N. Y. Acad. Sci. 1981, 365, 1-12. [CrossRef]

11. Drell, S.D.; Shultz, G.P.; Andreasen, S.P. A safer nuclear enterprise. Science 2012, 336, 1236. [CrossRef] [PubMed]

12. Murray, R.; Holbert, K.E. Nuclear Energy: An Introduction to the Concepts, Systems, and Applications of Nuclear Processes; Elsevier: Amsterdam, The Netherlands, 2014.

13. Howarth, P. An overview of current nuclear R\&D. Nature Rev. Phys. 2019, 1, 174-176. 
14. The Safety of Radioactive Waste Management: Achieving International Acceptable Solutions. Available online: https://www. iaea.org/sites/default/files/publications/magazines/bulletin/bull42-3/42302680518.pdf (accessed on 24 November 2021).

15. Macfarlane, A.M. The overlooked back end of the nuclear fuel cycle. Science 2011, 333, 1225-1226. [CrossRef]

16. World Commission on the Ethics of Scientific Knowledge and Technology. The Precautionary Principle. Available online: https:/ / unesdoc.unesco.org/ark:/48223/pf0000139578 (accessed on 24 November 2021).

17. Foster, C.E. Science and the Precautionary Principle in International Courts and Tribunals; Cambridge University Press: Cambridge, MA, USA, 2011.

18. Sands, P. The Greening of International Law: Emerging Principles and Rules. Indiana J. Glob. Leg. Stud. 1994, 1, $293-324$.

19. Trouwborst, A. Precautionary Rights and Duties of States; Martinus Nijhoff Publishers: Leiden, The Netherlands, 2006.

20. Sandin, P. Dimensions of the Precautionary Principle. Hum. Ecol. Risk Assess. Int. J. 1999, 5, 889-907. [CrossRef]

21. Katz, D. The Mismatch between the Biosafety Protocol and the Precautionary Principle. Georget. Int. Environ. Law Rev. 2001, 13, 949-982.

22. Geistfeld, M. Implementing the Precautionary Principle. Environ. Law Report. News Anal. 2001, 31, 11326-11333. [CrossRef]

23. Steel, D. Philosophy and Precautionary Principle: Science, Evidence and Environmental Policy; Cambridge University Press: Cambridge, MA, USA, 2015.

24. Steele, K. The Precautionary Principle: A New Approach to Public Decision-Making. LawProbab. Risk 2006, 5, 19-32. [CrossRef]

25. Applegate, J.S. The Taming of the Precautionary Principle. William Mary Environ. Law Policy Rev. 2002, $27,13-78$.

26. O'Riordan, T.; Cameron, J. Interpreting the Precautionary Principle; Routledge: London, UK, 2013.

27. McIntyre, O.; Mosedale, T. The Precautionary Principle as a Norm of Customary International Law. J. Environ. Law 1997, 9, 221-242. [CrossRef]

28. Huang, Y. Refining the Precautionary Principle in Public International Law. US-China Law Rev. 2020, 17, 75-91. [CrossRef]

29. Gullett, W. Environmental protection and the precautionary principle: A response to scientific uncertainty in environmental management. Environ. Plan. Law J. 1997, 14, 52-69.

30. Surtees, J. Important Concepts in Environmental Law: The Precautionary Principle. Law Now 2019, 43, 54-55.

31. Chen, L. Realizing the Precautionary Principle in Due Diligence. Dalhous. J. Leg. Stud. 2016, 25, 1-24.

32. De Sadeleer, N. The precautionary principle as a device for greater environmental protection: Lessons from EC courts. Rev. Eur. Commun. Int. Environ. Law 2009, 18, 3-10. [CrossRef]

33. Srinivasan, T.N.; Gopi Rethinaraj, T.S. Fukushima and thereafter: Reassessment of risks of nuclear power. Energy Policy 2013, 52, 726-736. [CrossRef]

34. Burns, S.G. The Impact of the Major Nuclear Power Plant Accidents on the International Legal Framework for Nuclear Power. Nucl. Law Bull. 2018, 101, 7-30.

35. Heller, M.A. Chernobyl Fallout: Recent IAEA Conventions Expand Transboundary Nuclear Pollution Law. Stanford J. Int. Law 1987, 23, 651-664.

36. Article 1 of the Convention on Early Notification of a Nuclear Accident; International Atomic Energy Agency (IAEA) Document INFCIRC/335; International Atomic Energy Agency (IAEA): Vienna, Austria, 1986.

37. United Nations Conference on Environment \& Development Rio de Janerio. Agenda 21. Available online: https: //sustainabledevelopment.un.org/outcomedocuments/agenda21 (accessed on 24 November 2021).

38. Adkins, M.; Griffiths, L.; Parr, S. Hudson Decision: An over-Precautionary Approach. Univ. New Brunsw. Law J. 2002, 51, $231-242$.

39. Reyners, P. The Convention on Nuclear Safety of 1994. Rev. Eur. Comp. Int. Environ. Law 1996, 5, 231-238. [CrossRef]

40. IAEA. Article 8 of Joint Convention on the Safety of Spent Fuel Management and on the Safety of Radioactive Waste Management; IAEA Document INFCIRC/546; IAEA: Vienna, Austria, 1997.

41. IAEA. Preamble of Joint Convention on the Safety of Spent Fuel Management and on the Safety of Radioactive Waste Management; IAEA Document INFCIRC/546; IAEA: Vienna, Austria, 1997.

42. IAEA. Vienna Declaration on Nuclear Safety: On Principles for the Implementation of the Objective of the Convention on Nuclear Safety to Prevent Accidents and Mitigate Radiological Consequences; IAEA Document INFCIRC/872; IAEA: Vienna, Austria, 2015.

43. Durand-Poudret, E. Towards a new international framework for nuclear safety: Developments from Fukushima to Vienna. Nucl. Law Bull. 2015, 95, 27-40. [CrossRef]

44. IAEA Nuclear Safety \& Security. Available online: http://www-ns.iaea.org/committees/css/ (accessed on 24 November 2021).

45. Operational Safety Review Team (OSART). Available online: https://www.iaea.org/sites/default/files/21/01/brochure_osart_ 2020.pdf (accessed on 24 November 2021).

46. Washington, M.J. The Practice of Peer Review in the International Nuclear Safety Regime. N. Y. Univ. Law Rev. 1997, 72, 430-469.

47. IAEA. Summary Report, IAEA Document CNS/6RM/2014/11_Final, Annex 1. In Proceedings of the Sixth Review Meeting of the Contracting Parties to the Convention on Nuclear Safety, Vienna, Austria, 24 March-4 April 2014.

48. Grossi, R.M. The safety of nuclear's future. Science 2021, 372, 1131. [CrossRef]

49. MOX Plant Case (Ireland v. United Kingdom) Transcript/Minutes. Day One. Available online: https://pcacases.com/web/ sendAttach/857 (accessed on 24 November 2021).

50. MOX Plant Case (Ireland v. United Kingdom) Transcript/Minutes. Day Eight. Available online: https://pcacases.com/web/ sendAttach/864 (accessed on 24 November 2021). 
51. MOX Plant Case (Ireland v. United Kingdom) Transcript/Minutes. Day Five. Available online: https://pcacases.com/web/ sendAttach/861 (accessed on 24 November 2021).

52. Joint Declaration of Caminos, Yamamoto, Park, Akl, Marsit, Eiriksson and Jesus. In the MOX Plant Case, Ireland v. the UK, Order of 3 December 2001.

53. Separate Opinion of Judge Anderson. In the MOX Plant Case, Ireland v. the UK, Order of 3 December 2001.

54. Separate Opinion of Judge Mensah. In the MOX Plant Case, Ireland v. the UK, Order of 3 December 2001.

55. Separate Opinion of Judge Treves. In the MOX Plant Case, Ireland v. the UK, Order of 3 December 2001. 3 December.

56. Separate Opinion of Judge Wolfum. In the MOX Plant Case, Ireland v. the UK, Order of 3 December 2001. 3 December.

57. Separate Opinion of Judge ad hoc Székely. In the MOX Plant Case, Ireland v. the UK, Order of 3 December 2001. 3 December.

58. Fisher, E. Is the precautionary principle justiciable? J. Environ. Law 2001, 13, 315-334. [CrossRef]

59. Luhmann, N.; Albrow, M. A Sociological Theory of Law; Routledge: New York, NY, USA, 2013.

60. Wynne, B. Uncertainty and environmental learning: Reconceiving science and policy in the preventative paradigm. Glob. Environ. Chang. 1992, 2, 111-127. [CrossRef]

61. Shrader-Frechette, K. Risk Analysis and Scientific Method: Methodological and Ethical Problems with Evaluating Societal Hazards; Springer Science \& Business Media: London, UK, 2012.

62. Vlek, C. A Precautionary-Principled Approach towards Uncertain Risks: Review and Decision-Theoretic Elaboration. Erasmus L Rev. 2009, 2, 129-169.

63. Gribbin, J. In Search of Schrodinger's Cat: Quantum Physics and Realityl; Bantam: New York, NY, USA, 2011.

64. Bergkamp, L.; Kogan, L. Trade, the Precautionary Principle, and Post-Modern Regulatory Process. Eur. J. Risk Regulat. 2013, 4, 493-508. [CrossRef]

65. Roughy, O.; Fisheries, A. Ignorance, the Precautionary Principle, and Sustainability. Ambio 1995, $24,92-97$.

66. Raffensperger, C.; Tickner, J. (Eds.) Protecting Public Health \& the Environment: Implementing the Precautionary Principle; Island Press: Washington, DC, USA, 1999.

67. Walker, W.E.; Harremoës, P.; Rotmans, J.; Van Der Sluijs, J.P.; Van Asselt, M.B.; Janssen, P.; Krayer von Krauss, M.P. Defining uncertainty: A conceptual basis for uncertainty management in model-based decision support. Integr. Assess. 2003, 4, 5-17. [CrossRef]

68. Sunstein, C.R. The paralyzing principle. Regulation 2002, 25, 32-37.

69. Sunstein, C.R. Laws of Fear; Cambridge University Press: Cambridge, UK, 2005.

70. Radiation Weighting for Reference Animals and Plants. Available online: https:/ /www.icrp.org/publication.asp?id=ICRP\%20 Publication\%20148 (accessed on 24 November 2021).

71. Nanda, V.P.; Pring, G.R. International Environmental Law and Policy for the 21st Centuryl, 2nd revised ed.; Martinus Nijhoff Publishers: Leiden, The Netherlands, 2012.

72. Dana, D. The Contextual Rationality of the Precautionary Principle. Queen's Law J. 2009, 35, 67-96.

73. MacLeod, J. Unifying the Precautionary Principle. Environ. Law Report. News Anal. 2004, 34, 10891-10896.

74. Fisher, E.C.; Jones, J.S.; von Schomberg, R. (Eds.) Implementing the Precautionary Principle: Perspectives and Prospects; Edward Elgar Publishing: Northampton, UK, 2006.

75. World Nuclear Power Plants in Operation. Available online: https:/ /www.nei.org/resources/statistics/world-nuclear-powerplants-in-operation (accessed on 24 November 2021).

76. Freese, C.H. The Commercial, Consumptive Use of Wild Species: Managing It for the Benefit of Biodiversity; WWF US: Washington, DC, USA; WWF International: Gland, Switzerland, 1996.

77. Carroll, S. Transboundary Impacts of Nuclear Accidents: Are the Interests of Non-Nuclear States Adequately Addressed by International Nuclear Safety Instruments. Rev. Eur. Comp. Int. Environ. Law 1996, 5, 205-210. [CrossRef]

78. Terms of Reference Commission on Safety Standards. Available online: https://www-ns.iaea.org/downloads/standards/css-tor. pdf (accessed on 24 November 2021).

79. Stone, C.D. Is there a precautionary principle. Envtl. L. Rep. News Anal. 2001, 31, 10790-10799.

80. Morris, J. (Ed.) Rethinking Risk and the Precautionary Principle; Butterworth-Heinemann: Oxford, UK, 2000.

81. Boutillon, S. The Precautionary Principle: Development of an International Standard. Mich. J. Int. Law 2002, 23, 429-470.

82. Goal 7 of the Agenda 2030. See Transforming Our World: The 2030 Agenda for Sustainable Development. Available online: https:/ /sdgs.un.org/2030agenda (accessed on 24 November 2021). 